Hydrology and Earth System Sciences, 9, 43-55, 2005

www.copernicus.org/EGU/hess/hess/9/43/

SRef-ID: 1607-7938/hess/2005-9-43

European Geosciences Union

\title{
Impact of phosphorus control measures on in-river phosphorus retention associated with point source pollution
}

\author{
B. O. L. Demars ${ }^{1}$, D. M. Harper ${ }^{2}$, J.-A. Pitt ${ }^{3}$, and R. Slaughter ${ }^{4}$ \\ ${ }^{1}$ The Macaulay Institute, Craigiebuckler, Aberdeen AB15 8QH, UK \\ ${ }^{2}$ Department of Biology, University of Leicester, Leicester LE1 7RH, UK \\ ${ }^{3}$ Environment Agency, Station Road, Haddiscoe, Gt Yarmouth, Norfolk, NR31 9JA, UK \\ ${ }^{4}$ Anglian Water, Henderson House, Lancaster Way, Huntingdon, Cambs. PE29 6XQ, UK
}

Received: 30 November 2004 - Published in Hydrology and Earth System Sciences Discussions: 13 January 2005 Revised: 17 May 2005 - Accepted: 25 May 2005 - Published: 14 June 2005

\begin{abstract}
In-river phosphorus retention alters the quantity and timings of phosphorus delivery to downstream aquatic systems. Many intensive studies of in-river phosphorus retention have been carried out but generally on a short time scale (2-4 years). In this paper, monthly water quality data, collected by the Environment Agency of England and Wales over 12 years (1990-2001), were used to model daily phosphorus fluxes and monthly in-river phosphorus retention in the lowland calcareous River Wensum, Norfolk, UK. The calibrated model explained $79 \%$ and $89 \%$ of the observed variance before and after phosphorus control, respectively. A split test revealed that predicted $T P$ loads were in good agreement with observed $T P$ loads $\left(r^{2}=0.85\right)$, although $T P$ loads were underestimated under high flow conditions. During relatively dry years, there was no net export of phosphorus from the catchment. High retention of phosphorus occurred, particularly during the summer months, which was not compensated for, by subsequent higher flow events. This was despite a relatively modest critical discharge $(Q)$ above which net remobilisation occur. Phosphorus removal from the effluent at two major STWs (Sewage Treatment Works) reduced phosphorus retention but not the remobilisation. This may indicate that the presence of impoundments and weirs, or overbank flows may have more control on the phosphorus dynamics under high flow conditions. Further phosphorus remedial strategies will be necessary to prevent downstream risks of eutrophication occurring independently of the unpredictable variability in weather conditions. More research is also needed to quantify the impact of the weir and overbank flows on phosphorus dynamics.
\end{abstract}

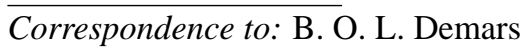

(b.demars@macaulay.ac.uk)

\section{Introduction}

Many studies have investigated the increase in phosphorus loads with runoff in natural streams (Crisp, 1966; Hobbie and Likens, 1973; McColl et al., 1975; Rigler, 1979; Meyer and Likens, 1979) and in rivers dominated by point source pollution (e.g. Edwards, 1971, 1973; Johnson et al., 1976; Harms et al., 1978). Long term annual mass balance studies of phosphorus have highlighted the great variability of phosphorus retention at catchment scale (Meyer and Likens, 1979; Baker and Richards, 2002). A large proportion of the annual phosphorus loads may be exported during short periods of high flows, particularly after a long period of low flows, during which there is high retention of phosphorus (e.g. Dorioz et al., 1989).

These types of studies, however, are rare (but see Rigler, 1979; Cooke, 1988; Dorioz et al., 1989, 1998; Svendsen and Kronvang, 1993; Jordan-Meille et al., 1998a). Generally the sampling frequency has not been high enough to quantify phosphorus exports during storm events (e.g. Moss et al., 1988; Johnes, 1996a). Government agencies typically collect regular water samples over the long term, but cannot afford to routinely monitor storm events. There are therefore, large uncertainties associated with the calculation of loads (Rigler, 1979; Webb et al., 1997, 2000; Phillips et al., 1999a), unless models are constructed to simulate continuous data (e.g. Verhoff et al., 1982; Webb et al., 2000). Calculated phosphorus mass balances may therefore reflect methodological discrepancies rather than true retention (e.g. Moss et al., 1988). Refinements of the export coefficient approach (e.g. Vollenweider, 1968; Johnes, 1996b) have been suggested to allow calculations of monthly mass balances (May et al., 2001), but serious limitations have so far prevented this approach from providing a reliable estimate of phosphorus retention.

(C) 2005 Author(s). This work is licensed under a Creative Commons License. 
Sophisticated models are now being used to simulate daily fluxes of phosphorus from different sources (e.g. Cooper et al., 2002a; Grizzetti et al., 2003). The estimates of phosphorus retention are still reliant, however, on measured T P (Total Phosphorus) loads at the catchment outlet (e.g. Grizzetti et al., 2003). This is because some critical processes such as floodplain sediment deposition during overbank flow events have not yet been modelled adequately. Power laws have been extensively used in geomorphology and hydrology to derive simple models (e.g. Knighton, 1998): these have been explored further to model phosphorus loads (e.g. Edwards, 1973; McColl et al., 1975) and phosphorus retention (e.g. Behrendt and Opitz, 2000). Uncertainties could then easily be propagated throughout the calculations of the loads, something which is seldom reported.

Nearly all European rivers drain populated areas, so the need to understand the contribution from both diffuse and point source pollution has long been recognised (e.g. Owens and Wood, 1968; Edwards, 1971). In England, point source pollution is the major source of phosphorus for most rivers (Muscutt and Withers, 1996). In-channel retention capacity can buffer, to some extent, the impact of point source phosphorus loads (Keup, 1968; Johnson et al., 1976; Harms et al.,1978; Moss et al.,1988; Haggard et al., 2001; Cooper et al., 2002b; Marti et al., 2004). Many published phosphorus budgets showed that annual inputs were higher than annual exports (Owens and Wood, 1968; Edwards, 1971, 1973; Moss et al., 1988; Johnes, 1996a). This is not the case however, in rivers where all the phosphorus retained in the river bed under low flow conditions is flushed during storm events, particularly during the autumn (Harms et al., 1978; Dorioz et al., 1989, 1998; Svendsen and Kronvang, 1993). There is thus an important difference in phosphorus dynamics between river systems, between years (Svendsen and Kronvang, 1993) or even along the longitudinal continuum of a single basin (Bowes et al., 2003). There has been growing pressure in Europe to decrease phosphorus inputs from point sources (Demars and Harper, 2002a) and many phosphorus control measures have been implemented to protect downstream lake ecosystems (e.g. Harper, 1992, Phillips et al., 1999b). Despite this, the runoff regime has remained a dominant control on phosphorus retention in natural and rural catchments (e.g. Meyer and Likens, 1979; Dorioz et al., 1989) and little effort has been made to estimate the impact of phosphorus control measures on in-river phosphorus retention over a range of flow conditions (but see Cooper et al., 2002a).

The objectives of this study were to develop:

1. a simple regression model to quantify daily phosphorus fluxes from background loads and point sources at the catchment scale using long term monthly monitoring data,

2. monthly calculations of phosphorus mass balance at catchment outlet with associated uncertainties, and
3. a clear representation of the impact of phosphorus removal over a range of flow conditions.

\section{Material and methods}

\subsection{Study area}

The River Wensum (Norfolk, UK) drains a $570 \mathrm{~km}^{2}$ rural catchment of Upper Chalk solid geology overlain by quaternary deposits (chalk boulder clay; glacial sand and gravel). The catchment area does not rise above $95 \mathrm{~m}$ OD. The rural landscape is dominated by pasture and arable fields, although scattered woodland still remains. The dominant industries are malting and poultry processing. The River Wensum is consequently rich in nitrate and phosphorus, but does not seem to be much impacted by other sources of pollution (Robson and Neal, 1997). Urban run-off is negligible at the catchment scale, the towns of Fakenham and East Dereham being relatively small, with about 8000 and 15000 inhabitants respectively (2000 data, Norfolk County Council). Average annual rainfall is $672 \mathrm{~mm}$ year $^{-1}$. The hydrograph displays a damped response to rainfall events due to the catchment permeability and runoff storage in the chalk aquifer. This is reflected by a base flow index of 0.73 at Costessey Mill (Institute of Hydrology, 1992). The effects of water abstraction on discharge did not exceed a maximum of $14 \%$ (generally 2-6\%) loss of mean weekly flows in the summers for the period 1971-1992 (Hiscock et al., 2001). The river channel has been substantially modified over the past centuries: impoundments and weirs were created to operate water mills for the grinding of flour. These engineering works are still in place but not in use. The consequence is that siltation occurs upstream of the weirs (Boar et al., 1994). The aquatic flora is very diverse and the river constitutes a prime example of a Ranunculus-dominated calcareous lowland river under the European Habitats Directive (92/43/EEC). River bank erosion is generally prevented by the development of riparian plants such as Glyceria maxima, Phalaris arundinacea or riparian woodland. More information can be found in Baker et al. (1978), Baker and Lambley (1980), Boar et al. (1994), Demars (2002), Demars and Harper (2002a, b).

\subsection{Phosphorus loads associated with diffuse sources}

The Spixworth Beck $\left(40.3 \mathrm{~km}^{2}\right)$ is a tributary of the River Bure adjacent to the River Wensum only impacted by diffuse sources (including septic tank leakages). It was previously used in two other nutrient budget studies (Moss et al., 1988; Johnes, 1996). The averaged T $P$ concentrations were: 56 ( \pm 25$) \mu \mathrm{g} \mathrm{L}^{-1}$ (1979-1980 data, Moss et al., 1988); 58 ( \pm 22$) \mu \mathrm{g} \mathrm{L}^{-1}$ (1989-1990 and 1995-1996 data; Johnes, 1996). This is very similar to the averaged $T P$ concentrations of four tributaries of the River Wensum only impacted by diffuse source pollution: $53( \pm 18) \mu \mathrm{gL}^{-1}$ (Fig. 1, sites 


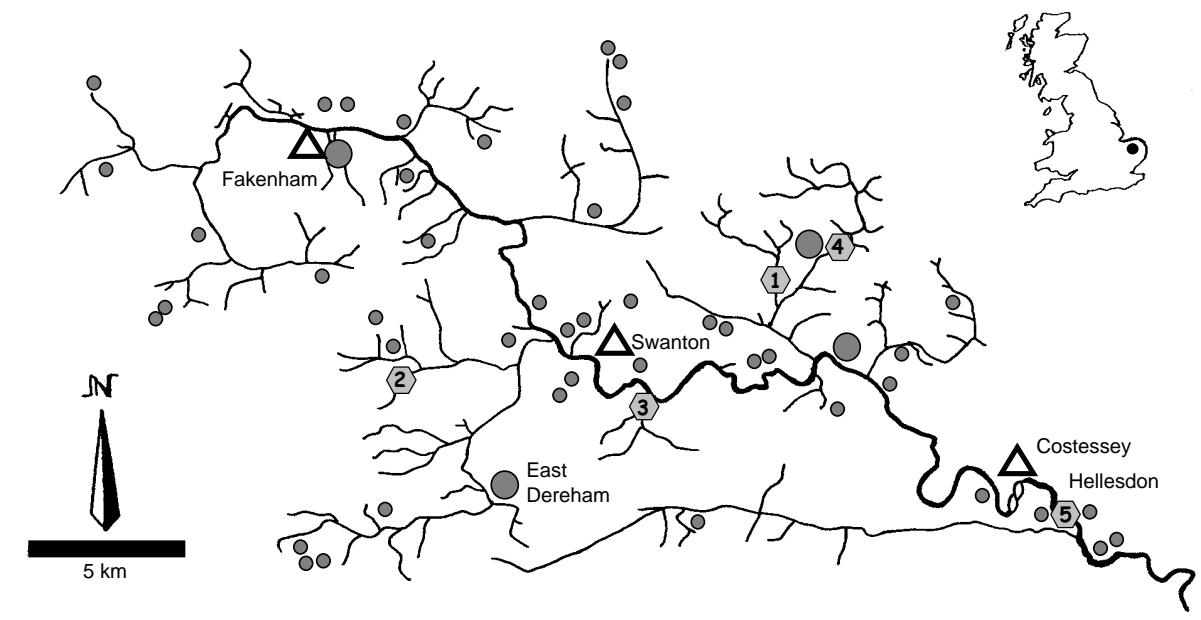

Fig. 1. Water quality monitoring sites (1-5), gauging stations $(\Delta)$ and point source effluents (filled circles) of the River Wensum, Norfolk, UK.

1-4, 2000-2001 data, Demars 2002). Assuming that this would represent typical concentrations for the whole catchment area of the River Wensum in the absence of point source effluents, these $T P$ concentrations can be used to calculate the $T P$ loads associated with diffuse sources at Costessey Mill (Fig. 1, site 5 - NGR TG 177 128). The data collected by Demars (2002) were only based on six sampling dates at different seasons, whereas the data analysed by Johnes (1996) were based on 93 sampling dates collected year round. Therefore, the latter only were used for subsequent analysis.

\subsection{Phosphorus loads derived from point source effluents}

The spatial distribution of the consented point source effluents (discharge $>5 \mathrm{~m}^{3}$ day $^{-1}$ ) are displayed in Fig. 1 . The Environment Agency (EA) monitored the total reactive phosphorus (TRP) of most STWs' final effluents between July 1993 and May 1996 to calculate the mean concentration of total reactive phosphorus (TRP). All the phosphorus analyses carried out for this study were based on Murphy and Riley (1962). The TRP was converted to $T P$ based on a TRP/TP ratio of 0.85 (Anglian Water Services data), which is very similar to previous studies (e.g. Harms et al., 1978). The loads were estimated with the derived mean flow (from the population equivalent or dry weather flow), but if neither was available, from the consented maximum daily flow. The STW effluents from a population equivalent (p.e.) of more than 500 collected the wastewater of $98 \%$ of the population connected to treatment plants; the phosphorus load was $1.86 \pm 0.36 \mathrm{~g} \mathrm{capita}^{-1}$ day $^{-1}$, similar to STW effluents of the Great Ouse and Bure catchments (Owens, 1970; Moss et al., 1988). For the unmonitored STW effluents an estimate per population equivalent (p.e.) was derived from the mean of all discharges from works with a p.e. less than 500, to calculate the loads.
Industrial effluent loads were estimated from the monitored (July 1993 to May 1996) mean T P concentrations (derived from mean TRP) and $80 \%$ consented maximum daily flow. The latter was to reflect the activity of the poultry processing industry (accounting for 56\% industrial T P loads) running at consented maximum flows during the week, but not at the weekend. The loads for these point sources were revised from those previously published in Demars and Harper (2002a, p. 36). Table 1 provides the $T P$ load characteristics for STWs (>500 p.e.). Uncertainty of the point source $T P$ loads was estimated as the weighted sum of the uncertainty of the individual effluents.

Removal of phosphorus by chemical precipitation with an iron salt started at two major STWs in autumn-winter 1999, following the technique adopted previously in the restoration of the Norfolk Broads (Harper, 1992; Thomas and Slaughter, 1992). Prior to this only primary (retention of coarse particles) and secondary (biological oxidation) treatments had been in operation at these STWs. The reduction of total phosphorus achieved (outlet/inlet of the STWs) was optimized at $77 \pm 9 \%$ for Fakenham (13439 p.e.) and $88 \pm 4 \%$ for East Dereham (17475 p.e., Demars, 2002). Near the outlet of the catchment (Costessey Mill, Fig. 1) the loads from point source effluents consequently decreased from 121 $( \pm 27) \mathrm{kg} \mathrm{day}^{-1}$ to $73( \pm 16) \mathrm{kg} \mathrm{day}^{-1}$, assuming that industrial effluents were running daily at $80 \%$ consented maximum flows. $T P$ concentrations of the final effluent stabilised at about $3.5 \mathrm{mg} \mathrm{L}^{-1}$ at Fakenham STWs and $2.0 \mathrm{mg} \mathrm{L}^{-1}$ at Dereham, after phosphorus stripping. Further treatment facilities would be required at these STWs to achieve greater phosphorus stripping efficiency without compromising the existing sanitary consents. Anglian Water Services (AWS) provided the phosphorus concentrations (total and soluble) of the crude sewage and final effluent of the two qualifying discharges (Fakenham and East Dereham STWs) before and 
Table 1. Summary statistics of the main sewage treatment works ( $>500$ p.e.) of the River Wensum catchment. The relative uncertainties of the total phosphorus $(T P)$ loads are noted $\delta x / x$. ${ }^{*}$ before phosphorus control measures.

\begin{tabular}{lccccc}
\hline STWs effluents & NGR & $T P$ kg day & $\delta x / x(\%)$ & p.e. & g capita $^{-1}$ day $^{-1}$ \\
\hline Bylaugh & TG 036 183 & 5.26 & 22.5 & 2913 & 1.81 \\
East Rudham & TF 835 285 & 1.15 & 19.5 & 560 & 2.05 \\
East Dereham* & TF 977 135 & 33.33 & 21.9 & 17475 & 1.91 \\
Fakenham* & TF 921 289 & 30.17 & 15.0 & 13439 & 2.25 \\
Foulsham & TG 026 243 & 1.57 & 25.1 & 998 & 1.57 \\
North Elmham & TF 998 213 & 2.06 & 22.5 & 1122 & 1.84 \\
Reepham & TG 104 227 & 7.58 & 18.1 & 4017 & 1.89 \\
RAF Sculthorpe & TF 833 312 & 1.78 & 27.4 & 1089 & 1.64 \\
Swanton Morley & TG 013 183 & 0.90 & 19.9 & 502 & 1.80 \\
\hline
\end{tabular}

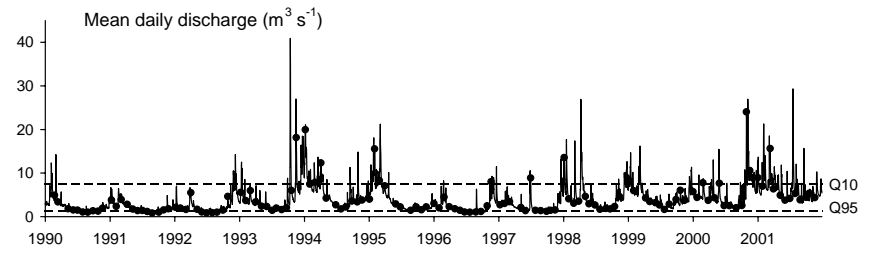

Fig. 2. Mean daily discharge (line) and sampling dates (filled circle).

after phosphorus removal. Further details can be found in Demars (2002) and Demars and Harper (2002a).

\subsection{Observed loads at Costessey Mill}

River phosphorus has been monitored monthly by the EA since January 1990 and fortnightly since March 2000 at Hellesdon Mill (NGR TG 198 104), about 4 km downstream from Costessey Mill, and above the confluence with the River Tud (Figs. 1-2). The discrepancy in catchment area between the gauging station (Costessey Mill) and the water quality monitoring station (Hellesdon Mill) was less than $2 \%$ and thus was neglected. Observed loads were estimated from the phosphorus concentration and mean discharge at the site on the day of sampling. Different phosphorus determinants were supplied by the Environment Agency over time: TRP from non-filtered samples for the whole period 1990-2001; soluble reactive phosphorus (SRP) from filtered samples for 2000-2001; and also T P for 1995-1996 and 2000-2001. An investigation of the quality of the data revealed that on several occasions TRP concentrations were much higher than $T P$ concentrations. This is likely to be due to analytical problems (see Neal et al., 2000; Jarvie et al., 2003). The relative uncertainty of the observed TRP concentration was about $20 \%$. The TRP concentrations were transformed into $T P$ concentration using the TRP/TP ratio calculated from available data. The TRP/TP ratios were 0.8 and 0.7 before and after phosphorus control, respectively with a $15 \%$ relative uncertainty.

\subsection{Discharge data at Costessey Mill}

The full run of data from the gauging station at Costessey Mill still need to be processed by the EA in order to account for gate movements upstream of the gauging station (EA, personal communication). There are many gaps in the record, particularly in recent years, and anomalous flow sequences. The long term mean daily flow hydrographs at the three gauging stations in the catchment (Fakenham, Swanton Morley and Costessey Mill) however, showed that the flow data at Costessey Mill were of good quality for the period 1990-1994. Costessey mean daily discharge $\left(Q_{571}\right)$ for the period 1995-2001 was estimated using Swanton Morley mean daily discharge $\left(Q_{398}\right)$ and after correction for differences in catchment area $(A)$ and one day time lag $(\tau)$ :

$\frac{\partial Q_{571}}{\partial t}=\frac{\partial Q_{398}}{\partial t-\tau} \cdot\left(\frac{A_{571}}{A_{398}}\right)$

with numbers in subscript representing the catchment area $\left(\mathrm{km}^{2}\right)$. A $10 \%$ uncertainty was associated with $Q$ to take into account measurement errors.

\section{Theory}

Within-system phosphorus retention is generally calculated with a mass balance approach (e.g. Vollenweider, 1975; House and Warwick, 1998; May et al., 2001). Few studies have tried to introduce explicitly a coefficient of in-stream retention. Johnes (1996) introduced a sediment trapping coefficient to calculate TP loads at the outlet of river catchments based on river gradient and nutrient concentration. However it is unlikely that an overall river gradient would take into account the effect of the weirs (stepped river bed, rather than gradual slope). Phosphorus retention associated with point sources can easily be calculated when background and 
point source loads are known (e.g. May et al., 2001). Weirs and impoundments, associated with water mills now not in use, have created stepped river systems where large stores of phosphorus are permanently present. In-lake phosphorus retention was best related to areal water loading or water residence time (e.g. Kirchner and Dillon, 1975; Larsen and Mercier, 1976). Therefore it is reasonable to assume that in-river phosphorus retention associated with point sources may be closely related to mean daily discharge from which it would be possible to derive a "critical flow" function characterising net retention/remobilisation. This novel approach is essentially an extrapolation technique (e.g. Verhoff et al., 1982; Webb et al., 2000) designed to extract new information from long term monthly monitoring data.

In-stream $T P$ loads $\left(\mathrm{kg} \mathrm{day}^{-1}\right)$ measured in the Spixworth Beck catchment were used to calculate background loads $(B)$ representing diffuse source pollution (including septic tank leakage). As the loads were derived from those actual instream measurements, they integrate both the degree of phosphorus pollution in the catchment and the biochemical processes in the floodplain, riparian zone and in-stream affecting these loads (May et al., 2001). In catchments impacted by point source effluents, in-stream $T P$ loads $\left(\mathrm{kg} \mathrm{day}^{-1}\right)$, were estimated as follows:

$T P=B+r \sum_{j} P_{j}$,

where $r$ is a coefficient of net $T P$ retention $(r<1)$ or remobilisation $(r>1)$ representing catchment processes associated with the sum of the point source inputs $\left(P_{j}\right.$ in $\left.\mathrm{kg} \mathrm{day}^{-1}\right)$. These processes include phosphate adsorption/desorption within the river bed, sedimentation/transport of particles and biological uptake/release. This model allows the assessment of the relative proportion of background (diffuse) loads and point sources contributing to the $T P$ loads. It also allows the study of the impact of point source phosphorus control measures on retention.

Assuming that the variability in $B$ can adequately be represented by a regression equation including mean daily discharge $Q\left(\mathrm{~m}^{3} \mathrm{~s}^{-1}\right)$ (see e.g. Verholff et al., 1982) and other relevant parameters $X_{i}$ (see e.g. Dorioz et al., 1988), then it follows:

$\frac{\partial B}{\partial t}=\frac{f_{1}\left(Q, X_{i}\right)}{\partial t}$.

From Eq. (2) and knowing $B$ the observed coefficient of retention/remobilisation $r_{o b s}$, associated with point sources $P_{j}$, was calculated as follows:

$r_{o b s}=\frac{T P_{o b s}+B}{\sum_{j} P_{j}}$,

with $T P_{o b s}$ observed $T P$ loads at the catchment outlet.

Since there was a tight relationship between $T P$ loads and discharge in lowland rivers highly impacted by point sources
Table 2. Values and uncertainties (standard error) of the parameters before and after phosphorus removal.

\begin{tabular}{lcccc}
\hline & \multicolumn{2}{c}{$1990-1999$} & \multicolumn{2}{c}{$2000-2001$} \\
\hline$a$ & 0.637 & \pm 0.129 & 0.637 & \pm 0.129 \\
$b_{0}$ & 2.294 & \pm 0.482 & 2.294 & \pm 0.482 \\
$b_{1}$ & 0.249 & \pm 0.052 & 0.249 & \pm 0.052 \\
$c$ & 0.112 & \pm 0.007 & 0.173 & \pm 0.016 \\
$d$ & 0.389 & \pm 0.031 & 0.287 & \pm 0.124 \\
\hline
\end{tabular}

and weirs $\left(r^{2}=0.92\right.$ in the River Wensum at Swanton Morley based on 40 samples collected fornightly during 20002001 and including high flow events), then the variability in $r$ should adequately be represented by regressing $r_{o b s}$ against mean daily discharge $Q\left(\mathrm{~m}^{3} \mathrm{~s}^{-1}\right)$ :

$\frac{\partial r}{\partial t}=\frac{f_{2}(Q)}{\partial t}$.

Calculation of the $T P$ mass balance, $R(\mathrm{~kg})$, then estimates the phosphorus dynamics of the system associated with the sum of the point source inputs:

$R=\left(B+f_{2}(Q) \sum_{j} P_{j}\right)-\left(B+\sum_{j} P_{j}\right)$.

With $R<0$, there is a net retention of $T P$. With $R>0$ there is a net remobilisation of $T P$. At equilibrium, it follows from Eq. (6), that the critical discharge under which there is neither $T P$ retention nor remobilisation is:

$f_{2}(Q)=1$

The parameters of $f_{2}(Q)$ were calibrated for the periods preceding and following phosphorus control measures at point sources to work out the impact of phosphorus stripping on retention $(R)$. Because the hydrological conditions are unlikely to be identical in these two periods, it was necessary to standardise $R$ with the discharge to make the data comparable. The variability of discharge was best represented by a flow duration curve built using long term data sets of the mean daily discharge (1990-2001). The x-axis represents the percentage of time the discharge is exceeded (e.g. $Q_{95}$ is the flow which was exceeded for $95 \%$ of the time) and the y-axis represents $Q$. $R$ was then calculated for each $Q$ corresponding to a known percentage of time flow exceeded.

\section{Results}

\subsection{Calibration}

The mean daily discharges at Costessey Mill predicted from Swanton Morley gauging station were regressed against the observed mean daily discharge data at Costessey Mill for 


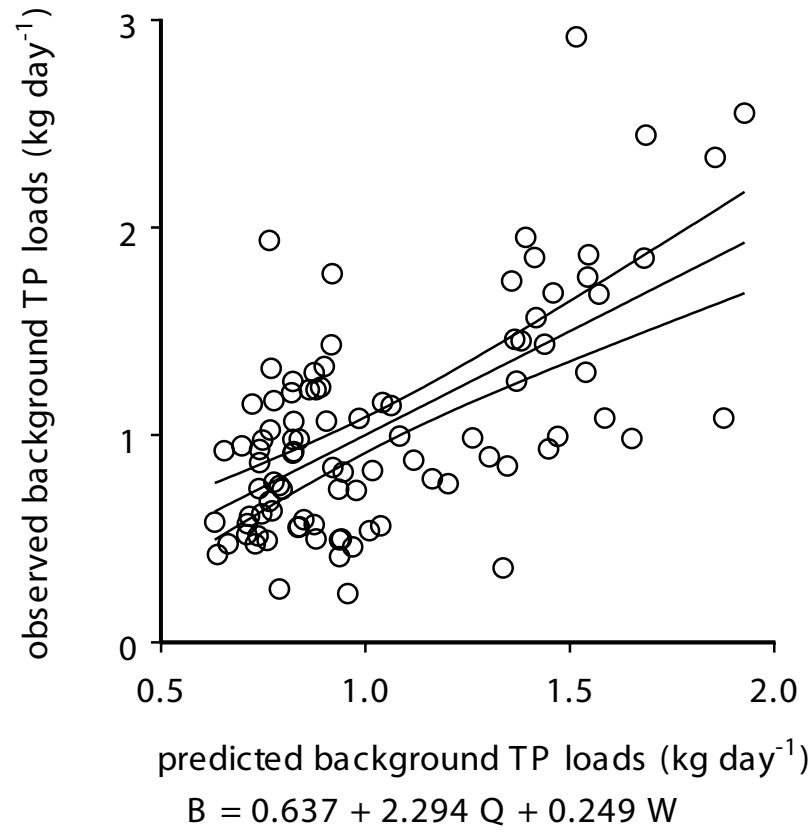

Fig. 3. Observed background loads $B$ against predictions with $Q$ mean daily discharge $\left(\mathrm{m}^{3} \mathrm{~s}^{-1}\right), W$ categorical variable for seasonality (+1 Dec-Feb, -1 Mar-Nov), and $a, b_{0}, b_{1}$ constants (see Table 2$)$. Linear regression $\left(r^{2}=0.39\right)$ with $95 \%$ confidence interval.

the period 1990-1994. The relationship was very tight $\left(r^{2}=0.926\right)$.

The background loads were best predicted using a multiple regression including mean daily discharge $Q$ and a winter effect $W$. The resulting calculation was:

$B=a+b_{0} Q+b_{1} W$

with $W$ a categorical variable taking the value 1 for winter (December-February) and -1 for the other seasons (MarNov). The value of the parameters are reported in Table 2. The regression coefficient was $r^{2}=0.39$. The fit is illustrated in Fig. 3.

The coefficient of retention/remobilisation $r$ was best predicted, both before and after phosphorus removal, by a simple linear regression against mean daily discharge $Q$ :

$r=c Q+d$.

The value of the parameters are reported in Table 2 . The regression coefficients were $r^{2}=0.73$ and $r^{2}=0.85$ before and after phosphorus removal respectively. The fits are illustrated in Fig. $4 a$ and $4 b$.

The critical flow function was therefore:

$Q=\frac{1-d}{c}$.

In-stream $T P$ loads at the oulet of the catchment calculated with Eq. (2) were very well calibrated to the observed data. They explained $79 \%$ and $89 \%$ of the observed variance before and after phosphorus control, respectively. And the slope was close to 1:1 (Fig. 5a and 5b).
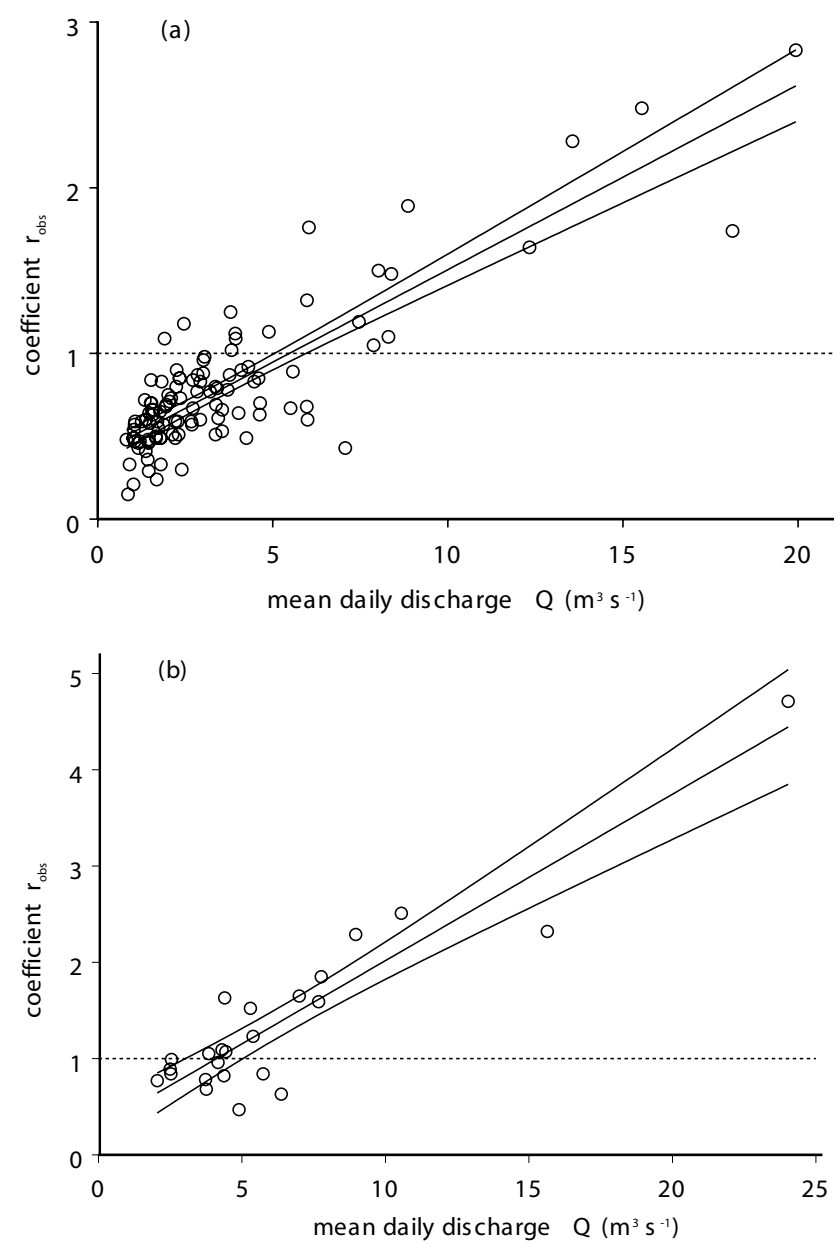

Fig. 4. Observed coefficient of retention/remobilisation against mean daily discharge before (a) and after (b) phosphorus control measures, with respective linear regression of $r^{2}=0.73, r^{2}=0.85$ and $95 \%$ confidence interval. The dotted line represents the dynamic equilibrium between retention $\left(r_{o b s}<1\right)$ and remobilisation $\left(r_{\text {obs }}>1\right)$.

\subsection{Error propagation}

Errors have been propagated as absolute uncertainties (standard deviation $\delta x)$ or relative uncertainties $(\delta x / x)$. Table 2 reports the standard error associated with the parameters for the period 1990-1999 and 2000-2001. These errors were then propagated throughout the calculations as follows for additions and subtractions: $\delta(x \pm y)=\left[(\delta x)^{2}+(\delta y)^{2}\right]^{1 / 2}$ and multiplications: $\delta(x y) / x y=\left[(\delta x / x)^{2}+(\delta y / y)^{2}\right]^{1 / 2}$. The above error propagations assumed that the uncertainties of $x$ and $y$ were independent and so may partially cancelled each other out. This was not the case when the daily $R$ was summed to provide monthly $R$ or when monthly $T P$ retention was cumulated over the whole study period. In these cases the daily errors were simply added. 

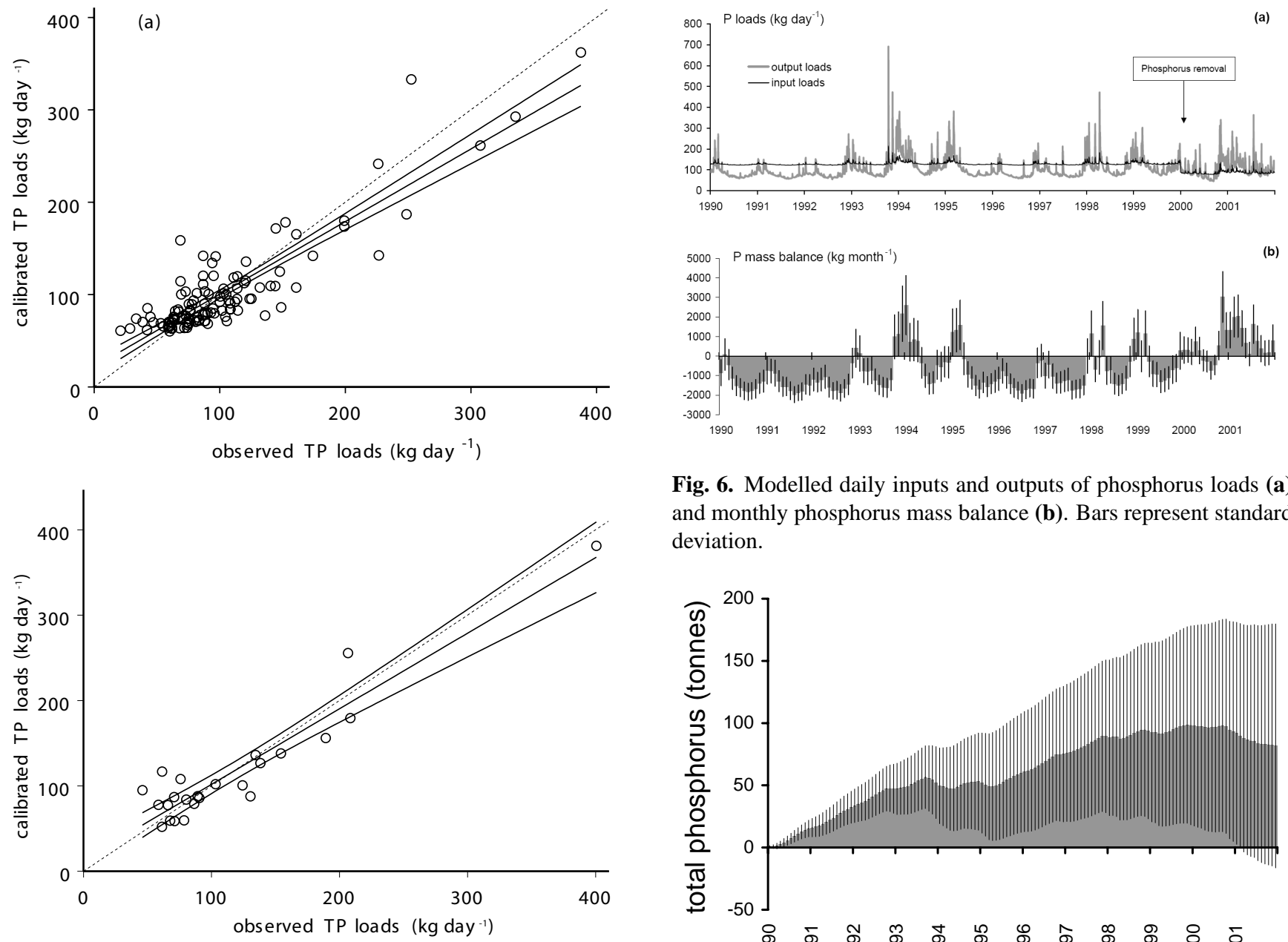

Fig. 6. Modelled daily inputs and outputs of phosphorus loads (a) and monthly phosphorus mass balance (b). Bars represent standard deviation.

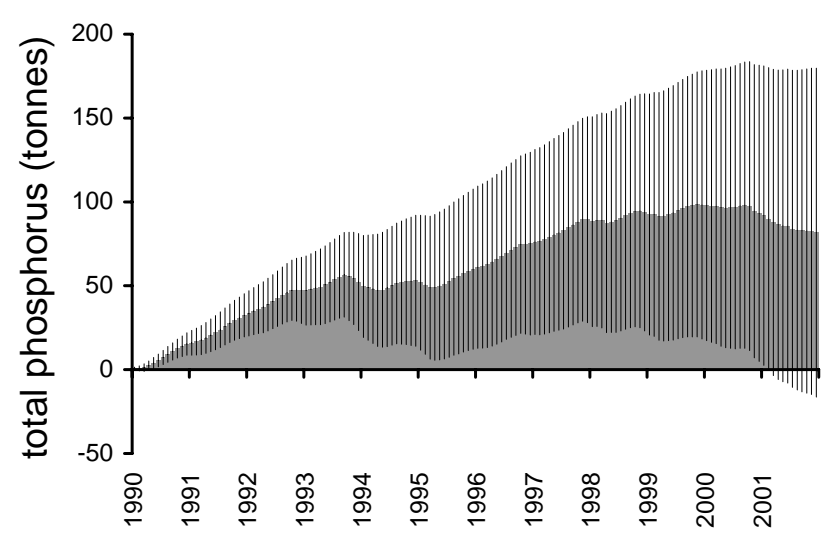

Fig. 5. Calibrated against observed TP loads before (a) and after (b) phosphorus control measures, with respective linear regression of $r^{2}=0.79, r^{2}=0.89$ and $95 \%$ confidence interval. The dotted line represents the expected 1:1 slope.

\subsection{Mass balance}

The daily input loads dramatically exceeded the daily output loads under low flow conditions, which are a common feature of the summer months (Fig. 6a and 6b). There was therefore an accumulation of phosphorus in the river system and this was not compensated by remobilisation during autumnwinter higher flow conditions (Fig. 7).

The drop in input loads in early 2000 (Fig. 6a) resulting from phosphorus removal was reflected in the annual loads, although the decrease in point source inputs was compensated by an increase in diffuse sources (Fig. 8). From Figs. 68 , it is therefore not clear what proportion of the resulting mass balance in the period 2000-2001 was due to phosphorus control or to different weather conditions.

Figure 9 shows the change in phosphorus mass balance due to phosphorus control over a range of mean daily flow conditions $\left(Q_{99}-Q_{1}\right)$, based on the flow duration curve de-

Fig. 7. Cumulative phosphorus retention of the River Wensum catchment area. Bars represent standard deviation.

rived from the studied period (1990-2001). Phosphorus control reduced the phosphorus retention at $Q_{99}$ from -64 to $-43 \mathrm{~kg} \mathrm{day}^{-1}$ but had no significant effects on phosphorus remobilisation at $Q_{1}$ (note complete overlap of uncertainties in Fig. 9). The critical discharges above which net remobilisation would occur were $5.5( \pm 0.5) \mathrm{m}^{3} \mathrm{~s}^{-1}\left(Q_{21}\right)$ and $4.1( \pm 1.8) \mathrm{m}^{3} \mathrm{~s}^{-1}\left(Q_{43}\right)$ before and after phosphorus control, respectively (Eq. 7; Fig. 9).

\subsection{Split test}

The regression coefficient provided above referred only to the calibration step. A split test was conducted to try to assess the robustness of the model. Data from the period 1990-1999 (before P removal) were split in two periods to conduct the test: 1990-1995 (six years) and 1996-1999 (four years). The first period of record (1990-1995) was used to parameterise Eq. (2) above. The second period (1996-1999) was used to calculate the predicted TP loads. Finally the predicted TP 

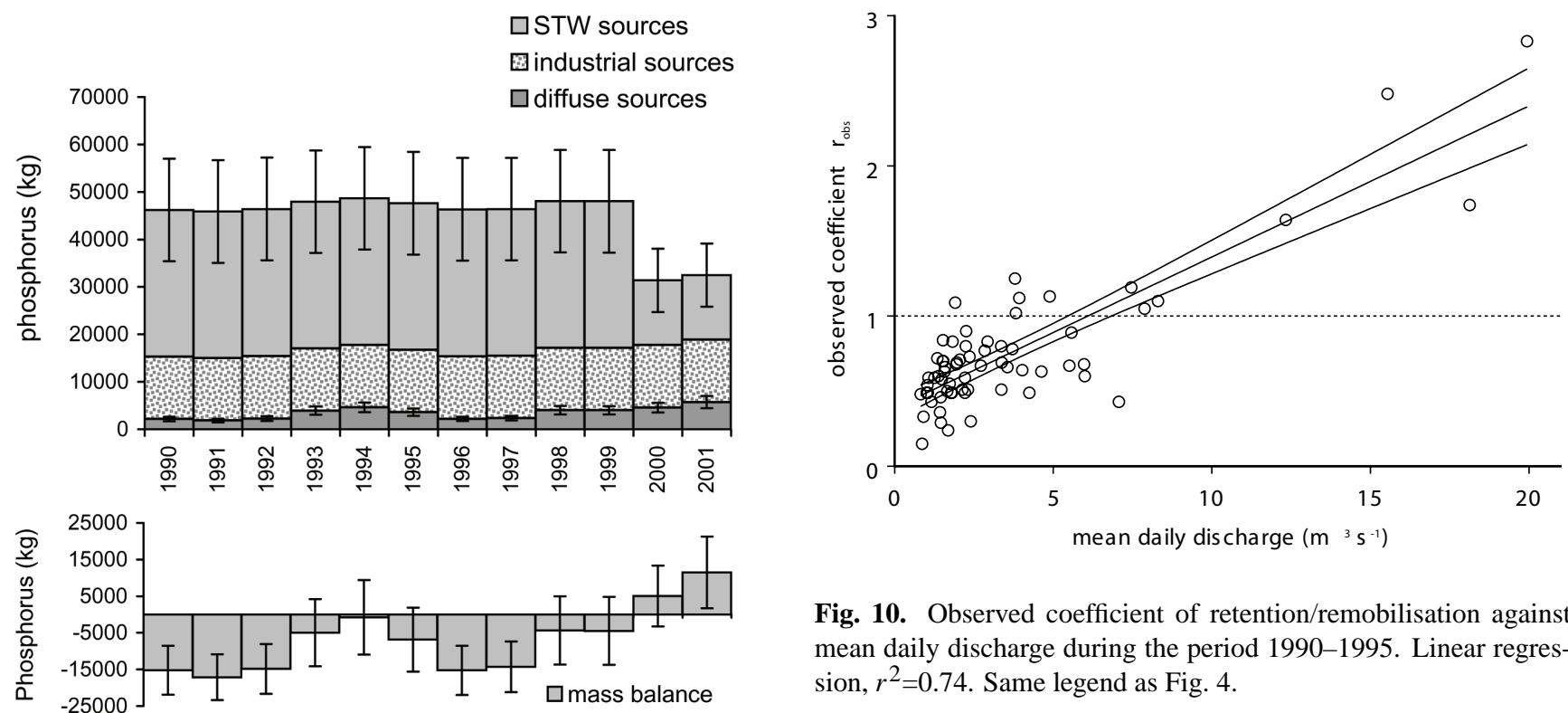

Fig. 8. Mean annual phosphorus loads, source apportionment and mass balance before and after phosphorus control measures. Bars represent standard deviation. Uncertainties of point source loads (from STWs and industry) were pulled together for clarity.

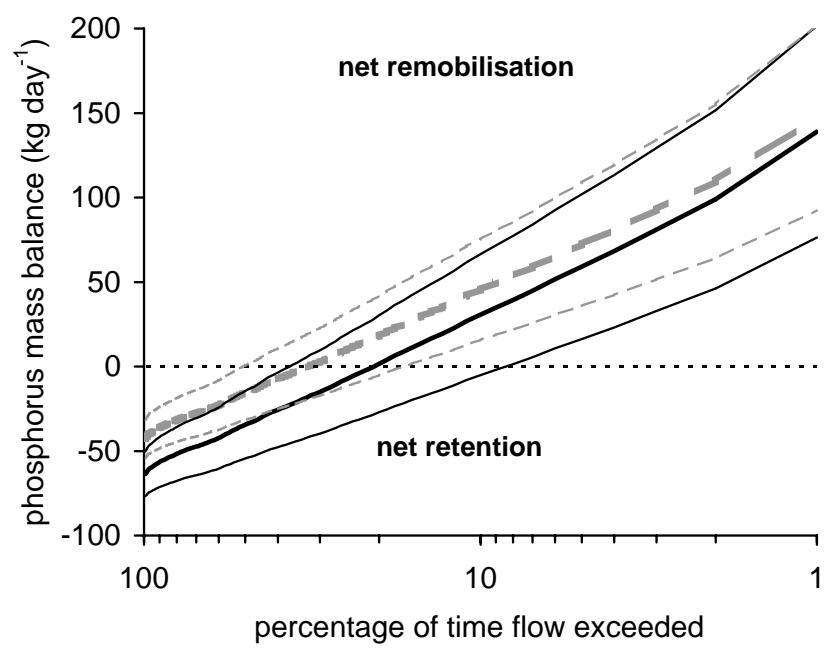

Fig. 9. Phosphorus mass balance before (black lines) and after (grey dashed lines) phosphorus control measures over $Q_{99}-Q_{1}$ chance flow exceedance. Thinner lines represent standard deviation.

loads were regressed against the observed TP loads of the second period. The regression of $r_{o b s}$ against $Q$ for the period 1990-1995 was good, with $r^{2}=0.74$ (Fig. 10). The regression of predicted against observed $T P$ loads for the period 1996-1999 had an equally good fit $\left(r^{2}=0.85\right)$ but predicted $T P$ loads were underestimated under high flow conditions (Fig. 11). This may indicate genuine differences between the two periods, although more high flow events would be needed for each period to carry out more robust test. 
Equation (3) is not assessing very well the amount of background TP loads $B\left(r^{2}=0.39\right)$. This is because a whole range of factors other than discharge and seasonality are likely to significantly impact the background TP loads $B$. However the data collected by governmental organisation is generally not sufficient to test individual parts of more complicated models. More intensive monitoring in catchments not impacted by point sources would be necessary to explore the well known effects of timing of peak flows (first flush effect).

The use of fixed TRP/TP ratios for each period (before and after phosphorus stripping) was a simplification. The concentration of particulate phosphorus $(P P)$ is known to increase during storm events (e.g. Harms et al., 1978), but the relationship between PP and discharge is generally weak and complex (e.g. Meyer and Likens, 1979; Svendsen and Kronvang, 1993; House et al., 1998). Moreover, suspended solid concentrations were generally under $10 \mathrm{mg} \mathrm{L}^{-1}$ and did not exceed about $100 \mathrm{mg} \mathrm{L}^{-1}$ even under high flow events in the River Wensum (Fig. 12; Edwards, 1971). This is comparable to groundwater fed lowland chalk rivers (Evans and Johnes, 2004), but smaller by an order of magnitude to other lowland rivers (e.g. Kronvang, 1992; Evans and Johnes, 2004).

It may seem slightly surprising that phosphorus load per capita $\left(1.86 \pm 0.36 \mathrm{~g} \mathrm{capita}^{-1}\right.$ day $\left.^{-1}\right)$ was similar to STW effluents of the Great Ouse and Bure catchments (Owens, 1970; Moss et al., 1988) given that there has been a general assumption that per capita phosphorus loads have reduced since the 1970s as a result of lower phosphorus detergents. However it is possible that this is negated by industrial sources of phosphorus being treated at these STWs (e.g. a laundry at Fakenham).

During storm events there is an hysteresis of the $T P$ concentration - discharge relationship in rivers, a time lag of the chemograph compared to the hydrograph (e.g. Cahill et al., 1974) or an exhaustion of $T P$ concentrations before the hydrograph peak (Dorioz et al., 1989, Svendsen and Kronvang, 1993). This is the consequence of several related factors (Meyer and Likens, 1979; Rigler, 1979; Jordan-Meille et al., 1998b). It could have been implemented in the model (see Webb et al., 2000) but its impact on monthly $T P$ mass balance is deemed to be negligible. The hydrological conditions preceding the storm events may actually be more important than the magnitude of the storm event itself for $T P$ flux (Dorioz et al., 1989, 1998; Svendsen and Kronvang, 1993; Jordan-Meille et al., 1998a). However, there were not enough data to investigate the impact of peak flows on $T P$ export in different seasons. Since the calibration of the model was good $\left(r^{2} \geq 0.8\right)$, this effect may not be so pronounced in the River Wensum catchment.

Further work should strive to quantify better the outflow discharge of industrial and small STW effluents to better quantify their contributions to the total budget. This stresses how important it is to quantify uncertainties. In more sophisticated models, sensitivity analysis must be carried out (see

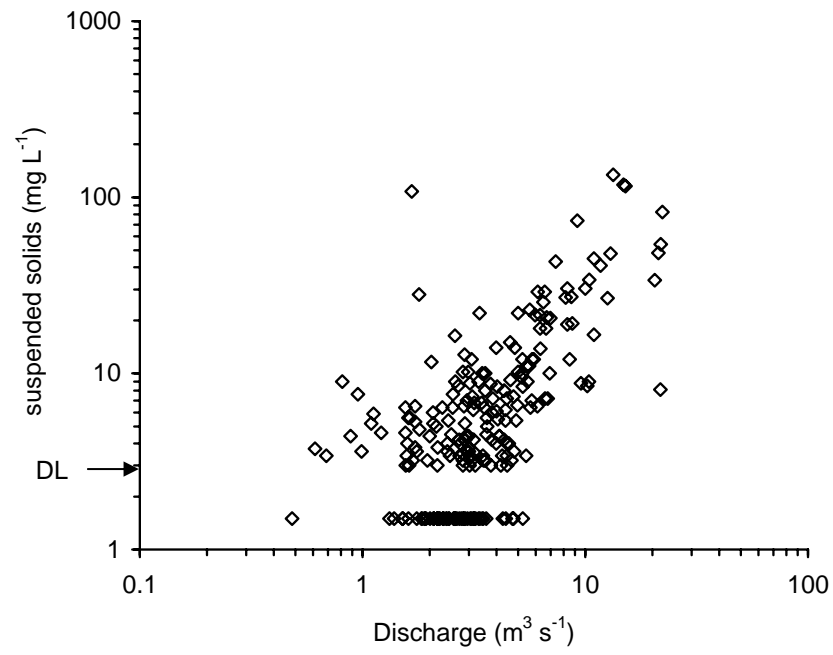

Fig. 12. Suspended solids concentrations increases with discharge (period 1981-1990). DL means analytical detection limit.

e.g. Cooper et al., 2002a) and the fit of the model must be reported (see e.g. Grizzetti et al., 2003).

The approach developed in this study will perform best in lowland rivers where background loads are little compared to point source loads and where $\mathrm{P}$ storage in the river sediment is only partially affected during high flows. Both conditions are of general interests since many rivers have been highly polluted by point sources (see e.g. Muscutt and Withers, 1996) and most rivers have been engineered all across the lowlands of industrial countries and can potentially have huge TP stores in the sediment (see e.g. Demars and Harper, 2002a).

\subsection{Phosphorus retention}

One of the striking results of this study is that large retention occurred during the dry seasons which was not even slightly compensated by high flow events. There are several processes leading to phosphorus retention in river basins: adsorption onto suspended particles (House et al., 1995) or fine sediments (Klotz, 1988; House and Warwick, 1999), siltation in impoundments above the weirs and in macrophyte patches and riparian habitats (Svendsen and Kronvang, 1993; Demars and Harper, 2002b) and floodplain deposition during overbank flow events (Walling, 1999). Phosphorus coprecipitation with calcium is likely to be negligible (Neal, 2001; Demars and Harper, 2002b). From the numerous studies that have quantified the phosphorus uptake by aquatic plants, it can be concluded that the biological transient storage of phosphorus by these primary producers is negligible ( $<1 \%$ of $T P$ flux) in the Wensum catchment (see Westlake, 1968; Ladle and Casey, 1971; Svendsen and Kronvang, 1993; House et al., 2001). Some phosphorus is removed from the channel when the impoundments above the weirs are dredged or during the EA's weed cutting programme. However these operations are limited to small sections of the main 
river channel (EA, personal communication). One major sink of phosphorus is likely to be overbank floodplain sedimentation during high flow events (Malanson, 1993; Walling, 1999; Owens et al., 2001; Bowes and House, 2001; Tockner et al., 2002). Walling (1999) estimated that on average $40 \%$ of the sediment budget of UK rivers are deposited on the floodplain. Since floodplain retention is a long term sink $\left(10^{2}-10^{4}\right.$ years) in UK rivers due to low rates of bank erosion (Walling, 1999), it would explain the lack of net remobilisation observed under high flows at the outlet of the River Wensum catchment. The lack of net remobilisation is due to the low water power of lowland rivers further reduced by the reduction of slope by impoundments and the high energy loss at the weirs associated with the water mills. Sedimentation upstream of the weirs may be another significant sink. A weir of several metres high can create siltation of the river bed on several kilometres due to the gentle slope of the River Wensum $1.1 \mathrm{~m} \mathrm{~km}^{-1}$ (see Demars and Harper, 2002b). Finally the silt has a high content of TP: $2.3( \pm 0.7) \mathrm{mg} \mathrm{g}^{-1}$ (Demars and Harper, 2002a). In conclusion, huge stores of TP exist upstream from the weir. During high flows a relatively small proportion of this pool of $T P$ is washed down the system. This has probably explain the tight relationship between discharge $Q$ and $T P$ loads, and allowed us to simplify dramatically our approach. It may also explain partly why the net remobilisation has not changed immediately after phosphorus removal.

Intensive studies have shown that the majority of the total annual phosphorus load is exported out of a catchment during the highest flow events (e.g. Johnson et al., 1976; Meyer and Likens, 1979; Rigler, 1979; Cooke, 1988; Jordan-Meille et al., 1998a). This may not be the case however, in populated lowland rivers. There is generally a large retention of phosphorus (coming from point sources) by the river bed during low flow conditions, as observed in many studies of populated river catchments (e.g. Harms et al., 1978; Dorioz et al., 1989, 1998; Svendsen and Kronvang, 1993), although the sediment adsorption capacity can become saturated (e.g. Marti et al., 2004). Floodplain processes, and net built-up of phosphorus in the sediment above the weirs, are likely to be responsible for the discrepancy in phosphorus export observed in previous studies (e.g. Moss et al., 1988; Johnes, 1996a).

\subsection{Climate variability and phosphorus control measures}

Many studies have produced graphs to show catchment phosphorus retention variability with increasing discharge (Duffy et al., 1978; Meyer and Likens, 1979). Others have plotted phosphorus export against flow duration curves (Johnson et al., 1976). In this study the $T P$ mass balance was plotted against the percentage of time flow exceeded before and after phosphorus removal at the two STWs. This had the advantage of clearly illustrating the impact of phosphorus control, after taking into account the impact of discharge vari- ability (see Fig. 9). The $40 \%$ decrease in point source loads was accompanied by a $35 \%$ decrease in phosphorus retention under low flows $\left(Q_{95}\right)$, but had no impact on phosphorus remobilisation under high flow conditions (see Fig. 9). The resulting effect was a lowering (but note wide overlap in the uncertainties in Fig. 9) of the critical discharge above which there is a net remobilisation of phosphorus from $Q_{21}$ to $Q_{43}$. The lack of change in remobilisation under the highest flow conditions (above $Q_{5}$ ) may be due to a time lag in the flushing of sediments previously exposed to very high TP concentrations. However soluble reactive phosphorus concentrations were still predicted to be around 608 and 185 $\mu \mathrm{g} \mathrm{L}^{-1}$ under low flow $\left(Q_{95}\right)$ and median flow $\left(Q_{50}\right)$ conditions respectively, after phosphorus removal, at the outlet of the catchment (Demars and Harper 2002a, p. 41). These concentrations are up to one order of magnitude higher than the zero Equilibrium Phosphate Concentration of the River Great Ouse (House and Denison, 1997). Therefore net sediment release of phosphate is still very unlikely to happen. The lack of change in phosphorus remobilisation may indicate that the phosphorus dynamics under high flows may be primarily controlled by physical processes such as those generated by past engineering work and overbank flows. What would be the effect of the removal of the weirs on the phosphorus dynamics?

\subsection{Management implications}

The present approach has allowed to extract substantial information on phosphorus dynamics from monitoring data generated by a governmental agency (EA) and a private water company (AWS). Yet, the monitoring strategy could be improved. First, streams not polluted by point sources were not part of the monthly monitoring scheme, despite the fact that Moss et al. (1988) had already identified and monitored the Spixworth Beck in the late 1970s. Further monitoring of the Spixworth Beck was only undertaken as part of additional projects (Johnes, 1996). This was also highlighted earlier on in a review of 990 monitoring stations from East Anglia (Evans, 1999). The monitoring strategy should include a set of streams not polluted by point sources. Additional research projects could be commissioned to study more intensively this particular set of streams. This would allow better parameterisation of Eq. (3). Second, there was a good survey of point source phosphorus concentrations, but the associated discharge data were not so reliable. At least some of these discharge data are measured continuously. They should be collected routinely alongside phosphorus concentration data and hold into a shared database ready for use. Third, the regular maintenance of discharge measurements (within and) at the outlet of the catchment is critical. The implementation of such improvements would be cost effective due to the associated benefits, e.g. better understanding of pollutant dynamics, leading to possible reconsideration of management strategies. 
This study indicated that in lowland, low gradient rivers such as the Wensum there is a remarkable degree of phosphorus retention within the catchment, but this does not negate the need to control anthropogenic phosphorus inputs to the system. In the past, biological effects of eutrophication have been particularly pronounced in this river during low flow years. Actions to ensure that designated habitats remain in, or are restored to, favourable condition, need to be taken on a catchment-wide basis, and should ideally be informed by an improved understanding of both the short and long-term dynamics of the system.

Significant financial investment has been required of the water industry, which at Fakenham STW has allowed further phosphorus removal, down to $<1 \mathrm{mgL}^{-1} P$ in the final effluent, since the completion of the present study. This work now has tertiary phosphorus removal using sand filters with integrated ferric sulphate injection. A similar scheme at East Dereham STW is under construction and will soon be meeting the same levels of phosphorus removal. In a move towards a more catchment-based eutrophication control plan, phosphorus removal has also been initiated at the major industrial input to the river, a poultry processing plant, reducing typical effluent concentrations from ca. $12 \mathrm{mg} \mathrm{L}^{-1} P$ to $<1 \mathrm{mg} \mathrm{L}^{-1} P$. The impact of these substantial reductions in $P$ inputs from the major point sources in the catchment should now be assessed, alongside the remaining contributions from small STWs and diffuse agricultural inputs, in order to inform future management and investment decisions.

\section{Conclusions}

High in-channel retention of phosphorus occurred during the summer period under low flow conditions. This retained phosphorus did not appear at the catchment outlet during subsequent high flow events. It was inferred that the floodplain together with impoundments above the weirs associated with water mills constituted long term sinks (and potentially long term sources) of phosphorus coming from point sources. Further studies should now focus on the quantification of the sedimentation processes and phosphorus uptake/release mechanisms above the weirs, in the riparian habitat and the floodplain. The removal of the effect of a weir would be a key experiment to further our understanding of phosphorus dynamics. Specific studies should also be carried out in streams not impacted by point source effluents so that background loads can be better assessed.

The $T P$ loads at the outlet of the catchment were not much lower after phosphorus control measures. This was mainly due to an increase in background $T P$ loads during wet years. This study devised a system to calculate the impact of point source phosphorus control measures for any given runoff (climatic condition). The phosphorus removal at two major STWs had an immediate effect on the reduction of TP retention but not yet on TP net remobilisation. This study makes it clear that further phosphorus remedial strategies would be necessary to reduce downstream risks of eutrophication.

Acknowledgements. The data were originally acquired for R\&D project P2-127, funded by the Environment Agency (EA), Anglian Water Services (AWS) and English Nature. Penny Johnes provided the TP concentration data of the Spixworth Beck. The ideas were developed at the Macaulay Institute where the first author was funded by Scottish Executive Environment and Rural Affairs Department (MLU/792/01). J. Kemp, B. Koo, T. Edwards, two anonymous referees and the editor A. Montanari provided helpful comments on earlier versions of the manuscript.

Edited by: A. Montanari

\section{References}

Baker, D. B. and Richards, R. P.: Phosphorus budgets and riverine phosphorus export in Northwestern Ohio watersheds, J. Environ. Qual., 31, 96-108, 2002.

Baker, R., Driscoll, R. J., and Lambley, P.: The River Wensum (1) Fakenham to Lyng. Trans, Norfolk and Nor. Nat. Soc., 24, 179197, 1978.

Baker, R. and Lambley, P.: The River Wensum (2), Trans. Norfolk and Nor. Nat. Soc., 25, 64-83, 1980.

Behrendt, H. and Opitz, D.: Retention of nutrients in river systems: dependence on specofic runoff and hydraulic loads, Hydrobiologia, 410, 111-122, 2000.

Boar, R. R., Lister, D. H., Hiscock, K. M., and Green, F. M. L.: The effects of water resources management on the Rivers Bure, Wensum and Nar in North Norfolk, University of East-Anglia, Norwich, 1994.

Bowes, M. J. and House, W. A.: Phosphorus and dissolved silicon dynamics in the River Swale catchment, UK: a mass-balance approach, Hydrol. Process., 15, 261-280, 2001.

Bowes, M., House, W. A., and Hodgkinson, R. A.: Phosphorus dynamics along a river continuum, Sci. Total Environ., 313, 199212, 2003.

Cahill, T. H., Imperato, P., and Verhoff, F. H.: Evaluation of phosphorus dynamics in a watershed, J. Env. Eng. Div.-ASCE, 100, 439-458, 1974.

Cooke, J. G.: Sources and sinks of nutrients in a new Zealand hill pasture catchment, II. Phosphorus, Hydrol. Process., 2, 123-133, 1988.

Cooper, D. M., House, W. A., Reynolds, B., Hughes, S., May, L., and Gannon, B.: The phosphorus budget of the Thame catchment, Oxfordshire: 2. Modelling, Sci. Total Environ., 282/283, 435-457, 2002a.

Cooper, D. M., House, W. A., May, L., and Gannon, B.: The phosphorus budget of the Thame catchment, Oxfordshire, UK 1. Mass balance, Sci. Total Environ., 282/283, 233-251, 2002b.

Crisp, D. T.: Input and output of minerals for an area of Pennine moorland: the importance of precipitation, drainage, peat erosion and animals, J. Appl. Ecol., 3, 327-348, 1966.

Demars, B. O. L.: Aquatic vascular plants in nitrate-rich calcareous lowland streams: do they respond to phosphorus enrichment and control?, PhD thesis, University of Leicester, 2002. 
Demars, B. O. L. and Harper, D. M.: Assessment of the impact of nutrient removal on eutrophic rivers, Rep. No. P2-127/TR, Environment Agency, Bristol, 2002a.

Demars, B. O. L. and Harper, D. M.: Phosphorus in a lowland calcareous river basin: a multiscale approach to understanding human impacts, Int. J. Ecohydrol. and Hydrobiol., 2, 149-164, $2002 b$.

Dorioz, J. M., Pilleboue, E., and Ferhi, A.: Phosphorus dynamics in watersheds: role of trapping processes in sediments, Water Res., 23, 147-158, 1989.

Dorioz, J.-M., Cassell, E. A., Orand, A., and Eisenman, K. G.: Phosphorus storage, transport and export dynamics in the Foron river watershed, Hydrol. Process., 12, 285-309, 1998.

Duffy, P. D., Schreiber, J. D., McClurkin, D. C., and McDowell, L. L.: Aqueous- and sediment-phase phosphorus yields form five southern pine watersheds, J. Environ. Qual., 7, 45-50, 1978.

Edwards, A. M. C.: Aspects of the chemistry of four East anglian rivers, $\mathrm{PhD}$ thesis, University of East Anglia, Norwich, 1971.

Edwards, A. M. C.: Dissolved load and tentative solute budgets of some Norfolk catchments, J. Hydrol., 18, 201-217, 1973.

Evans, G. L.: Phosphorus and its biological effect in lowland rivers, $\mathrm{PhD}$ thesis, University of Leicester, Leicester, 1999.

Evans, D. J. and Johnes, P.: Physico-chemical controls on phosphorus cycling in two lowland streams, Part 1 - the water column, Sci. Total Environ., 329, 145-163, 2004.

Grizzetti, B., Bouraoui, F., Granlund, K., Rekolainen, S., and Bidoglio, G.: Modelling diffuse emission and retention of nutrients in the Vantaanjoki watershed (Finland) using the SWAT model, Ecol. Model., 169, 25-38, 2003.

Haggard, B. E., Storm, D. E., and Stanley, E. H.: Effect of a point source input on stream nutrient retention, J. Am. Water Resour. As., 37, 1291-1299, 2001.

Harms, L. L., Vidal, P. H., and McDermott, T. E.: Phosphorus interactions with stream-bed sediments, J. Env. Eng. Div.-ASCE, 104, 271-288, 1978.

Harper, D. M.: Eutrophication of Freshwaters. Principles, Problems and Restoration, Chapman and Hall, London, 1992.

Hiscock, K. M., Lister, D. H., Boar, R. R., and Green, F. M. L.: An integrated assessment of long-term changes in the hydrology of three lowland rivers in eastern England, J. Environ. Qual., 61, 195-214, 2001

Hobbie, J. E. and Likens, G. E.: Output of phosphorus, dissolved organic carbon, and fine particulate carbon from Hubbard Brook watershed, Limnol. Oceanogr., 18, 734-742, 1973.

House, W. A., Denison, F. H., and Armitage, P. D.: Comparison of the uptake of inorganic phosphorus to a suspended and stream bed-sediment, Water Res., 29, 767-779, 1995

House, W. A., Jickells, T. D., Edwards, A. C., Praska, K. E., and Denison, F. H.: Reactions of phosphorus with sediments in fresh and marine waters, Soil Use Manage., 14 (supplement), 139146,1998

House, W. A. and Denison, F. H.: Nutrient dynamics in a lowland stream impacted by sewage effluent: Great Ouse, England, Sci. Total Environ., 205, 25-49, 1997.

House, W. A. and Warwick, M. S.: A mass-balance approach to quantifying the importance of i n-stream processes during nutrient transport in a large river catchment, Sci. Total Environ., 210/211, 139-152, 1998.

House, W. A. and Warwick, M. S.: Interactions of phosphorus with sediments in the River Swale, Yorkshire, UK, Hydrol. Process. 13, 1103-1115, 1999.

House, W. A., Duplat, D., Denison, F. H., Henville, P., Dawson, F. H., Cooper, D. M., and May, L.: The role of macrophytes in the retention of phosphorus in the river Thame, England, Chem. Ecol., 17, 271-291, 2001.

Institute of Hydrology: Low flow estimation in the United Kingdom. Report No. 108, Wallingford, 1992.

Jarvie, H. P., Neal, C., Withers, P. J. A., Robinson, A., and Salter, N.: Nutrient water quality of the Wye catchment, UK: exploring patterns and fluxes using the Environment Agency data archives, Hydrol. Earth Syst. Sc., 7, 722-743, 2003, SRef-ID: 1607-7938/hess/2003-7-722.

Johnes, P. J.: Nutrient export modelling - River Bure, Norfolk. Anglian Region Operational Investigation 581, Environment Agency, Peterborough, 1996a.

Johnes, P. J.: Evaluation and management of the impact of land use change on the nitrogen and phosphorus load delivered to surface waters: the export coefficient modelling approach, J. Hydrol., 183, 323-349, 1996b.

Johnson, A. H., Bouldin, D. R., Goyette, E. A., and Hedges, A. M.: Phosphorus loss by stream transport from a rural watershed: quantities, processes, and sources, J. Environ. Qual., 5, 148-157, 1976.

Jordan-Meille, L., Dorioz, J.-M., and Wang, D.: Analysis of the export of diffuse phosphorus from a small rural watershed, Agronomie, 18, 5-26, 1998a.

Jordan-Meille, L., Dorioz, J. M., and Mathieu, N.: An artificial flood to determine the hydrological network's contribution to phosphorus exports in a small rural watershed, Water Res., 32, 1801-1810, 1998b.

Keup, L. E.: Phosphorus in flowing waters, Water Res., 2, 373-386, 1968

Kirchner, W. B.: An examination of the relationship between drainage basin morphology and the export of phosphorus, Limnol. Oceanogr., 20, 267-270, 1975.

Kirchner, W. B. and Dillon P. J.: An empirical method of estimating the retention of phosphorus in lakes, Water Resour. Res., 11, 182-183, 1974.

Klotz, R. L.: Sediment control of soluble reactive phosphorus in Hoxie Gorge Creek, New York, Can. J. Fish. Aquat. Sci., 45, 2026-2034, 1988.

Knighton, D.: Fluvial forms and processes. Arnold, London, 1998.

Kronvang, B.: The export of particulate matter, particulate phosphorus and dissolved phosphorus from two agricultural river basin: implications on estimating the non-point phosphorus load, Water Res., 26, 1347-1358, 1992.

Ladle, M. and Casey, H.: Growth and nutrient relationships of Ranunculus penicillatus var calcareus in a small chalk stream. In Proceedings of the European Weed research Council. 5th International Symposium on Aquatic Weeds, European Weed Research Society, Oxford, 53-62, 1971.

Larsen D. P. and Mercier H. T.: Phosphorus retention capacity of lakes, J. Fish. Res. Board Can., 33, 1742-1750, 1976.

Malanson, G. P.: Riparian Landscapes. Cambridge University Press, Cambridge, 1993.

Marti, E., Aumatell, J., Godé, L., Poch, M., and Sabater, F.: Nutrient retention efficiency in streams receiving inputs from wastewater treatment plants, J. Environ. Qual., 33, 285-293, 2004. 
May, L., House, W. A., Bowes, M., and McEvoy, J.: Seasonal export of phosphorus from a lowland catchment: upper River Cherwell in Oxfordshire, England, Sci. Total Environ., 269, 117-130, 2001.

McColl, R. H. S., White, E., and Waugh, J. R.: Chemical run-off in catchments converted to agricultural use, New Zeal. J. Sci., 18, 67-84, 1975.

Meyer, J. L. and Likens, G. E.: Transport and transformation of phosphorus in a forest stream ecosystem, Ecology, 60, 12551269, 1979.

Moss, B., Balls, H., Booker, I., Manson, K., and Timms, M.: Problems in the construction of a nutrient budget for the River Bure and its Broads (Norfolk) prior to its restoration from eutrophication, In: Algae and the aquatic environment, edited by: Round, F. E., Biopress, Bristol, 327-353, 1988.

Murphy, J. and Riley, J. P.: A modified single solution method for the determination of phosphate in natural waters, Anal. Chim. Acta, 27, 31-36, 1962.

Muscutt, A. D. and Withers, P. J. A.: The phosphorus content of rivers in England and Wales, Water Res., 30, 1258-1268, 1996.

Neal, C.: The potential for phosphorus pollution remediation by calcite precipitation in UK freshwaters, Hydrol. Earth Syst. Sc., 5, 119-131, 2001, SRef-ID: 1607-7938/hess/2001-5-119.

Neal, C., Neal, M., and Wickam, H.: Phosphate measurement in natural waters: two examples of analytical problems associated with silica interference using phosphomolybdic acid methodologies, Sci. Total Environ., 251/252, 511-522, 2000.

Owens, M. and Wood, G.: Some aspects of the eutrophication of water, Water Res., 2, 151-159, 1968.

Owens, M.: Nutrient balances in rivers, Water Treat. Exam., 19, 239-247, 1970.

Owens, P. N., Walling, D. E., Carton, J., Meharg, A. A., Wright, J., and Leeks, G. J. L.: Downstream changes in the transport and storage of sediment-associated contaminants ( $\mathrm{P}, \mathrm{Cr}$ and $\mathrm{PCBs}$ ) in agricultural and industrialized drainage basins, Sci. Total Environ., 266, 177-186, 2001.

Phillips, G., Bramwell, A., Pitt, J., Stansfield, J., and Perrow, M.: Practical application of 25 years' research into the management of shallow lakes, Hydrobiologia, 395/6, 61-76, 1999 b.
Phillips, J. M., Webb, B. W., Walling, D. E., and Leeks, G. J. L.: Estimating the suspended sediment loads of rivers in the LOIS study area using infrequent samples, Hydrol. Process., 13, 10351050, 1999a.

Rigler, F. H.: The export of phosphorus from Dartmoor catchments: a model to explain variations of phosphorus concentrations in streamwater, J. Mar. Biol. Assoc. UK, 59, 659-687, 1979.

Robson, A. J. and Neal, C.: A summary of regional water quality for Eastern UK rivers, Sci. Total Environ., 194/195, 15-37, 1997.

Svendsen, L. M. and Kronvang, B.: Retention of nitrogen and phosphorus in a Danish lowland river system: implications for the export from the watershed, Hydrobiologia, 251, 123-135, 1993.

Thomas, C. and Slaughter, R.: Phosphate reduction in sewage effluents: some practical experiences, J. Inst. Water Env. Man., 6, 158-164, 1992.

Tockner, K., Malard, F., Uehlinger, U., and Ward, J. V.: Nutrients and organic matter in a glacial river-floodplain system (Val Roseg, Switzerland), Limnol. Oceanogr., 47, 266-277, 2002.

Verhoff, F. H., Melfi, D. A., and Yaksich, S. M.: An analysis of total phosphorus transport in river systems, Hydrobiologia, 91, 241-252, 1982.

Vollenweider, R. A.: Input-output models with special reference to the phosphorus loading concept in limnology, Schweiz. Z. Hydrol., 37, 53-84, 1975.

Walling, D. E.: Linking land use, erosion and sediment yields in river basins, Hydrobiologia, 410, 223-240, 1999.

Webb, B. W., Phillips, J. M., and Walling, D. E.: A new approach to deriving 'best-estimate' chemical fluxes for rivers draining the LOIS study area, Sci. Total Environ., 251/252, 45-54, 2000.

Webb, B. W., Phillips, J. M., Walling, D. E., Littlewood, I. G., Watts, C. D., and Leeks, G. J. L.: Load estimation methodologies for British rivers and their relevance to the LOIS RACS(R) programme, Sci. Total Environ., 194/195, 379-389, 1997.

Westlake, D. F.: The biology of aquatic weeds in relation to their management, In Proceedings of the 9th British Weed Control Conference, British Weed Control Council, Brighton, 371-381, 1968. 